\title{
Manajemen Konflik Komunikasi dalam Pengembangan Pariwisata Berbasis Masyarakat
}

\author{
Anggun Anindya Sekarningrum ${ }^{1}$, Puji Lestari ${ }^{2}$, Basuki Agus Suparno ${ }^{3}$ \\ 1,2,3 Magister Ilmu Komunikasi, Universitas Pembangunan Nasional "Veteran" Yogyakarta \\ Jl. Babarsari 2 Tambakbayan Yogyakarta, 55281, Indonesia \\ Email: anindya2909@gmail.com¹; puji.lestari@upnyk.ac.id ${ }^{2 *}$; basuki.agus@gmail.com³ \\ *Corresponding author
}

\begin{abstract}
Tourism management in Gunungkidul Regency is still a lot of conflicts, including conflict management in Watugupit, Purwosari Regency, and Buges Beach, Panggang Regency. The purpose of this study is to find a communication conflict management model that is applied in dealing with communication conflicts in community-based tourism development in managing tourism potential in Gunungkidul and to analyze the role of stakeholders in developing tourism potential in Gunungkidul. This research method uses qualitative research with a case study method. The results of the study found an innovative communication conflict management model consisting of three stages, namely planning, implementation, and evaluation. Innovation in managing conflict communication is needed with efforts that have dimensions of novelty and usefulness so that it is expected to have an impact on more concrete efforts and build community participation sustainably. The role of the Tourism Office as the person in charge of managing tourism potential in Gunungkidul is not optimal in dealing with the communication conflicts that occur and the local community is not much involved in designing, making decisions, or implementing policies in tourism management. This research contributes to the form of a conflict management model that can be applied to the tourism office in managing natural beauty in an area.
\end{abstract}

Keywords: Communication; Conflict Management; Innovative; Tourism

\begin{abstract}
Abstrak
Manajemen pariwisata di Kabupaten Gunungkidul masih banyak konflik, termasuk manajemen konflik di Watugupit, Kabupaten Purwosari dan Pantai Buges, Kabupaten Panggang. Tujuan penelitian ini adalah untuk menemukan model manajemen konflik komunikasi yang diterapkan dalam menangani konflik komunikasi dalam pengembangan pariwisata berbasis masyarakat dalam mengelola potensi wisata di Gunungkidul dan menganalisis peran pemangku kepentingan dalam mengembangkan potensi pariwisata di Gunungkidul. Metode penelitian ini menggunakan penelitian kualitatif dengan metode studi kasus. Hasil penelitian menemukan model manajemen konflik komunikasi inovatif yang terdiri dari tiga tahap, yaitu perencanaan, implementasi, dan evaluasi. Inovasi dalam mengelola komunikasi konflik diperlukan dengan upaya yang memiliki dimensi kebaruan dan kegunaan sehingga diharapkan berdampak pada upaya yang lebih konkret dan membangun partisipasi masyarakat secara berkelanjutan. Peran Dinas Pariwisata sebagai penanggung jawab pengelolaan potensi wisata di Gunungkidul tidak optimal dalam menangani konflik komunikasi yang terjadi dan masyarakat setempat tidak banyak terlibat dalam perancangan, pengambilan keputusan atau implementasi kebijakan dalam pengelolaan pariwisata. Penelitian ini memberikan kontribusi berupa model manajemen konflik yang dapat diterapkan pada dinas pariwisata dalam mengelola keindahan alam di suatu daerah.
\end{abstract}

Kata kunci: Komunikasi; Manajemen Konflik; Inovatif; Pariwisata

\section{Pendahuluan}

Pembangunan pariwisata yang tidak melibatkan masyarakat sering menyebabkan rasa terpinggirkan masyarakat setempat sehingga dapat menimbulkan konflik yang pada akhirnya mengancam keberlanjutan pembangunan pariwisata itu sendiri. Pengembangan kepariwisataan berbasis masyarakat tidak dapat dipisahkan dengan proses komunikasi sosial yang melibatkan berbagai elemen di masyarakat.
Pengembangan pariwisata di Gunungkidul dengan menerapkan Community Based Tourism (CBT) memberikan peluang kepada masyarakat setempat untuk ikut serta mengelola objek-objek wisata di sekitarnya dan mendapatkan manfaat secara ekonomi atas pengelolaan tersebut. Dinas Pariwisata memiliki regulasi mengenai wisata di daerah, tetapi dalam pengelolaan dilakukan secara langsung oleh masyarakat 
lokal (community). Upaya yang dilakukan oleh Dinas Pariwisata untuk meningkatkan kualitas destinasi wisata adalah melakukan diskusi dengan mitra baik dari komunitas pengelola wisata, masyarakat sekitar maupun pihak swasta. Masyarakat membentuk kelompokkelompok yang memiliki tujuan yang sama untuk mengembangkan potensi wisata di daerah mereka. Kelompok sadar wisata ini mengelola potensi wisata dengan modal dan pengetahuan yang minim sehingga berjalan secara lamban.

Menurut data yang disampaikan Dinas Pariwisata Kabupaten Gunungkidul, masih ada beberapa destinasi wisata yang bermasalah dalam pengelolaan. Konflik yang terjadi di beberapa objek wisata melibatkan sejumlah operator atau kelompok sadar wisata (pokdarwis) yang masing-masing mengklaim memiliki hak untuk memandu wisatawan yang datang.

Konflikjuga terjadi di objek wisata Watugupit yang melibatkan dua desa. Objek wisata Watugupit merupakan salah satu primadona pariwisata Gunungkidul saat ini yang berada di antara dua desa menjadikan permasalahan tersendiri dalam pengembangannya. Persaingan dalam pengelolaan objek wisata menjadi konflik yang menyebabkan masyarakat di dua desa tersebut berselisih. Permasalahan juga terlihat pada pengelolaan objek wisata Pantai Gesing antara Dinas Pariwisata dan Pokdarwis setempat. Konflik terjadi karena adanya larangan pihak pengelola dan Pokdarwis dalam melakukan pemungutan jasa wisata oleh Dinas Pariwisata (Dispar) Gunungkidul. Hal ini dinilai sebagai keputusan sepihak dengan tidak mempertimbangkan unsur masyarakat yang telah merasa melakukan perintisan kawasan objek wisata yang kini menjadi daerah tujuan wisata. Permasalahan di Pantai Gesing terlihat dari banyaknya wisatawan yang mengeluhkan adanya double retribusi yang diterapkan di objek wisata tersebut. Dinas Pariwisata memberlakukan retribusi masuk kawasan objek Pantai Gesing, sedangkan dua kilometer setelah retribusi pertama terdapat pemungutan jasa dengan nominal yang sama dilakukan oleh pengelola pokdarwis Pantai Gesing. Konflik dalam pengelolaan pariwisata di Gunungkidul muncul karena adanya tarik ulur dalam pengelolaan dari pihak masyarakat, dinas terkait maupun swasta yang memiliki andil di dalamnya. Sengketa dalam pengelolaan yang terjadi mengindikasikan adanya sikap dari masyarakat yang belum siap dalam upaya pengembangan sektor kepariwisataan. Dinas Pariwisata yang menangani potensipotensi wisata di Gunungkidul terus berupaya memberikan pendampingan untuk peningkatan kapasitas sumber daya manusia (SDM) dalam pengelolaan. Kesadaran Pemerintah Daerah (Pemda) dinilai terlambat untuk merangkul masyarakat lokal. Pemda datang dengan regulasi dan menuntut Pokdarwis untuk mematuhinya sehingga menimbulkan ketegangan tersendiri antara masyarakat sebagai pengelola langsung dengan Pemda.

Kebijakan Perda yang mengatur pengelolaan pariwisata di Gunungkidul membutuhkan partisipasi masyarakat untuk menjalankannya. Proses sosialisasi di masyarakat maupun kelompok pengelola objek wisata sering melahirkan perbedaan yang mendasar, dimana penduduk asli merasa lebih kuat dan punya andil besar dalam mengembangkan objek wisata tersebut. Selain itu, hal yang menjadi penghambat implementasi kebijakan (Jupir, 2013), yaitu: 1) belum tersedianya sumber daya pendukung implementasi, 2) belum ada alokasi yang jelas, 3) belum optimalnya komunikasi dan koordinasi, dan 4) adanya kondisi eksternal (politik, sosial, dan ekonomi) yang tidak dapat dikendalikan.

Dalam mengembangkan potensi wisata semua lapisan pun harus dapat saling mendukung baik mulai dari pemerintahan sampai ke masyarakat untuk saling mengerti dan mendukung. Potensi wisata dapat memberikan damoak positif, seperti adanya upaya dalam pelestarian lingkungan, pelestarian nilai 
kearifan lokal, menambah pengetahuan pada generasi muda, dan meningkatkan kesejahteraan masyarakat(Nugraha \& Putri, 2016). Manajemen konflik harus dilaksanakan untuk melawan hasil yang merusak dan mempromosikan implikasi konstruktif dari konflik dalam pengelolaan pariwisata (Okazaki, 2008).

Penelitian mengenai manajemen konflik pembangunan Bandara di Kulon Progo dilakukan oleh Pamungkas, Rahardjo, Dwiningtyas, dan Pradekso (2015). Hasil penelitian tersebut menyatakan bahwa pemicu konflik, yaitu: 1) adanya pembangunan bandara, 2) adanya perbedaan dalam pandangan, 3) adanya provokator, 4) dan hoax tentang kehidupan masyrakat yang akan sengsara. Upaya yang dapat dilakukan untuk mengurai konflik dengan melakukan penghindaran konflik, saling mengungkapkan emosi, dan memanfaatkan pihak ketiga dalam pengurangan konflik masyarakat.

Penelitian mengenai manajemen konflik komunikasi dilakukan oleh Lestari, Prabowo, dan Wibawa (2012) yang menyatakan bahwa manajemen komunikasi bencana di Merapi sudah cukup baik, karena sudah dilakukan dengan pembuatan Rencana Kontigensi; Pengorganisasian dilakukan oleh Badan Nasional Penanggulangan Bencana (BNPB), Pemerintah Daerah Provinsi DIY, Pemda Sleman, Badan Penanggulangan Bencana Daerah (BPBD), serta ForumPenangggulanganResikoBencana(FPRB).

Penelitian serupa yang dilakukan oleh Lestari, DN, dan Hendariningrum (2009) yang menyatakan bahwa manajemen konflik berbasis nilai-nilai budaya lokal dapat ditangani dengan pola kompromi. Pola kompromi adalah pola untuk mengatasi konflik dengan nilai-nilai budaya lokal Yogyakarta, yaitu: 1) nilai religio-spritual, 2) nilai moral, 3) nilai kemasyarakatan, 4) nilai kepemimpinan dan pemerintah, 5) nilai kejuangan dan kebangsaan, dan 6) nilai semangat khas keyogyakartaan.
Secara konseptual, McKercher (2005) mengartikan konflik dengan campur tangan tujuan seseorang atau satu pihak dengan perilaku orang lain atau pihak lain. Konflik masyarakat dapat memperlihatkan suatu proses interaksi dan komunikasi yang dinamis dalam berbagai sosial budaya. Komunikasi dan interaksi merupakan pengikat dalam kehidupan masyarakat terhadap berbagai situasi yang tumbuh dan berkembang di masyarakat. Komunikasi dapat menjembatani pihak-pihak yang berkonflik ketika terjadi benturan sosial dan budaya. Tumbuhnya konflik dalam proses komunikasi terjadi akibat pelemparan pesan yang tidak memuaskan antara komunikan dengan komunikator.

Parson (dalam Putnam, 2006) menjelaskan konflik itu sebagai bentuk sosial, yang dengan menggunakan konsep sosialisasi yang menimbulkan ketegangan dan pertentangan itu memperjelas konflik. Konflik pasti melekat pada kehidupan masyarakat. Konflik sosial yang timbul dalam proses komunikasi, terjadi akibat penyampaian pesan yang tidak memuaskan antara komunikan dengan komunikator (Amin, 2017). Kegiatan pariwisata tidak dapat dipisahkan dari proses komunikasi sosial yang melibatkan semua elemen dalam masyarakat. Keterlibatan pemerintah, swasta dan masyarakat dalam pengembangan daerah wisata akan membawa tuntutan bagi partisipasi masyarakat. Ketidakadanya kesepahaman bersama mengenai pentingnya menjalin komunikasi dalam menyelesaikan konflik yang ada di objek wisata menjadi penghambat tercapainya tujuan tersebut.

Fokus penelitian ini dibandingkan dengan penelitian terdahulu dilakukan di objek wisata Watugupit di Kecamatan Purwosari dan Pantai Buron dan Gesing (Buges) di Padukuhan Bolang, Desa Girikarto, Kecamatan Panggang. Permasalahan yang terjadi di objek wisata di Kecamatan Purwosari dan Panggang ini terkait dengan kebijakan Perda yang mengatur retribusi masuk di masingmasing objek wisata. Objek wisata Watugupit dan Pantai Gesing merupakan objek wisata baru yang mulai berkembang di Gunungkidul. 
Berdasarkan latar belakang di atas tujuan penelitian ini untuk menemukan model manajemen konflik komunikasi yang diterapkan dalam menghadapi konflik komunikasi pengembangan pariwisata berbasis masyarakat dalam mengelola potensi wisata di Gunungkidul dan menganalisis peran stakeholders dalam mengembangkan potensi wisata di Gunungkidul.

\section{Konflik Komunikasi}

Konflik berasal dari kata latin Configere yang berarti saling memukul. Secara sosiologis, konflik diartikan sebagai suatu proses sosial antara dua orang atau lebih (bisa juga kelompok) dimana salah satu pihak berusaha menyingkirkan pihak lain dengan menghancurkannya atau membuatnya tidak berdaya. Shetach $(2009 ; 83)$ menyebutkan konflik terjadi sebagai bagian dari proses komunikasi dan tidak negatif atau positif. Konflik dapat dimaknai positif atau negatif tergantung pada sikap orang yang mengalaminya. Pada sikap yang negatif, konflik sering diartikan sebagai perselisihan yang mengakibatkan dua orang atau lebih saling mengtalahkan sehingga salah satu atau kedua-duanya merasa terganggu. Pada sikap yang positif, konflik sering diartikan sebagai perselisihan antara dua orang atau lebih yang saling berjuang mencapai tujuan tanpa harus bekerjasama. Konflik positif tidak menimbulkan adanya perasaan terganggu salah satu atau kedua belah pihak.

Komunikasi sebagai salah satu dari banyak variabel yang membentuk konflik (Putnam, 2006). Proses komunikasi sebagai salah satu sumber konflik. Hubungan antara komunikasi dan konflik memiliki empat jenis yaitu, komunikasi sebagai variabel, sebagai proses, sebagai interpretatif, dan sebagai pola dialektika. Menurut Edwin B. Elippo (dalam Usman, 2001), komunikasi mendorong orangorang lain untuk menafsirkan suatu ide dengan cara yang diinginkan oleh si pembicara atau penulis. Pesan akan berpengaruh di masyarakat, karena melalui komunikasi manusia dapat mengikat hubungan sesama dan sebaliknya dapat menimbulkan kesenjangan dan konflik yang berkepanjangan. Konflik sosial dalam proses komunikasi sering ditimbukan akibat pesan yang disampaikan dalam setiap aktivitas pertukaran pesan, baik dalam komunikasi interpesonal, antarpersona, kelompok, media maupun dalam bentuk komunikasi massa.

Konflik dapat menjadi hasil dari ketidakseimbangan kekuatan struktural atau jika salah satu pihak yang terlibat tampaknya mengendalikan semua kekuatan. CBT dapat menjadi penyebab konflik karena salah satu pemangku kepentingan memonopoli sumber daya baru. Selain itu, penyebab konflik dalam CBT dapat berasal dari perbedaan di antara anggota masyarakat, kurangnya suara pilih yang tidak didengar atau diperhitungkan dalam proses pengambilan keputusan tentang bagaimana mengelola atau menggunakan CBT sebagai sumber daya, dan penyebaran pekerjaan dan waktu untuk membangun dan memperkenalkan produk CBT Plummer (2006: 501).

Thomas menjelaskan lima simpul kompetisi, kolaborasi, kompromi, penghindaran, dan akomodasi. Kelima pilihan manajemen konflik ini diposisikan dan diklasifikasikan dalam kaitannya dengan tingkat ketegasan dan kerja sama mereka. Melalui manajemen konflik, pelaku konflik dapat memiliki sikap positif terhadap konflik yang sedang terjadi. Mengelola konflik bertujuan untuk menciptakan situasi fungsional bagi pencapaian tujuan bersama. Berdasarkan Puspita (2018:71) model manajemen konflik dapat dibedakan menjadi enam bentuk, yaitu: (1) model integratif; (2) model interaktif; (3) stimulasi; (4) distributif; (5) pengurangan konflik; dan (6) model manajemen konflik yang inovatif (Curcija, 2016).

Sebagai sarana manajemen konflik, perencanaan pariwisata harus memasukkan konsensus di antara para pemangku kepentingan tentang arah pembangunan yang sesuai. 
Untuk mengembangkan konsensus di antara para pemangku kepentingan, perencana pariwisata harus dapat belajar bagaimana menangani ketidakpastian dengan membangun lingkungan yang mendorong dialog dan pembelajaran di antara para pemangku kepentingan (Timur \& Getz, 2008; Wray, 2011).

\section{Teori Konflik}

Konflik menjelaskan sosiologi banyak dijadikan kategori penjelasan utama untuk analisis perubahan sosial dan 'kemajuan (Coser, 1956 dalam Yang, 2013:83). Proses sosial didefinisikan sebagai "reaksi terus-menerus dari orang-orang yang didorong oleh kepentingan yang sebagian bertentangan dengan kepentingan rekan-rekan mereka, dan sebagian sesuai dengan kepentingan orang lain." Lewis A. Coser berpendapat bahwa perubahan sosial tidak semata terjadi melalui proses penyesuaian nilai-nilai yang membawa perubahan, tetapi terjadi akibat adanya konflik yang menghasilkan kompromikompromi yang berbeda dengan kondisi semula.

Coser menggambarkan konflik sebagai perselisihan mengenai nilai-nilai atau tuntuan yang berkenan dengan status, kekuasaan, dan sumber-sumber kekayaan yang dari persediaannya tidak mencukupi. Coser juga menyatakan perubahan menuju paradigma konflik dengan menyarankan bahwa konflik ada di mana-mana dan merupakan bagian yang melekat dari hubungan sosial. Pada dasarnya konflik juga dapat membantu fungsi komunikasi. Sebelum konflik, kelompok-kelompok mungkin tidak percaya terhadap posisi musuh mereka, tetapi akibat konflik, posisi dan batas antar kelompok ini sering menjadi diperjelas. Individu mulai mampu memutuskan untuk mengambil tindakan yang tepat dalam hubungannya dengan musuh mereka. Konflik juga memungkinkan pihak yang bertikai menemukan ide yang lebih baik mengenai kekuatan relatif mereka dan meningkatkan kemungkinan untuk saling mendekati atau saling berdamai.
Sebagaimana yang dikemukan oleh C. Bartos dan Wehr (2002: 26) teori Coser memberi jalan bagi penjelasan tindakan koersif dan fase konflik mendefinisikan konflik sebagai situasi pada saat para aktor menggunakan perilaku konflik melawan satu sama lain untuk menyelesaikan tujuan yang berseberangan atau mengekspresikaan naluri permusuhan. Unsur perilaku konflik sebagai unsur pemicu terjadinya konflik, sebab incompatible goal dan hostility feeling membutuhkan perilaku konflik secara sosial. Coser memberikan pembagian konflik menjadi realities dan nonrealities. Pembagian ini menjadi dasar atau kunci pembuka untuk menggunakan berbagai instrument teori konflik fungsional Coser.

Berdasar latar belakang tersebut tujuan penelitian ini untuk menemukan model manajemen konflik komunikasi yang diterapkan dalam menangani konflik komunikasi dalam pengembangan pariwisata berbasis masyarakat dalam mengelola potensi wisata di Gunungkidul dan menganalisis peran pemangku kepentingan dalam mengembangkan potensi pariwisata di Gunungkidul.

\section{Metode Penelitian}

Jenis penelitian ini adalah penelitian deskriptif kualitatif. Pendekatan penelitian yang dipilih dalam penelitian ini adalah pendekatan studi kasus. Peneliti dapat mengkaji perspektif informan yang memiliki otoritas, data, informasi, sertaketerkaitanlainnyadalammanajemenkonflik komunikasi pariwisata berbasis masyarakat di Kabupaten Gunungkidul Yogyakarta. Lokasi penelitian ini dilakukan di Kecamatan Purwosari dengan objek wisata Watugupit dan Pantai Buron dan Gesing (Buges) di Padukuhan Bolang, Desa Girikarto, Kecamatan Panggang.

Sumber data primer adalah sumber data yang diperoleh langsung dari responden atau objek yang diteliti. Dalam hal ini, data primer dikumpulkan dari para responden kunci (key respondents) antara lain keterangan atau informasi 
dari masyarakat setempat yang berpartisipasi langsung dalam pengelolaan objek wisata. Menurut Maleong (2001: 157) adalah sumber data yang diperoleh melalui dokumen-dokumen tertulis, arsip maupun yang lainnya pada instansi yang berhubungan dengan penelitian. Data sekunder diperoleh secara tidak langsung melalui laporan-laporan, buku-buku, atau data yang diolah, seperti data yang telah dipublikasikan baik dalam bentuk surat kabar dan literatur yang berhubungan dengan masalah yang diteliti.

Teknik pengumpulan data yang digunakan adalah melalui observasi, wawancara mendalam dan dokumentasi. Validitas data dalam penelitian ini menggunakan triangulasi data. Tringulasi adalah teknik pemeriksaan keabsahan data yang memanfaatkan sesuatu yang lain di luar data itu untuk keperluan pengecekan atau sebagai pembanding terhadap data itu. Data yang telah terkumpul dari hasil penelitian, baik yang diperoleh kuesioner atau angket, interview, observasi dan dokumentasi diolah secara kuantitatif dan juga kualitatif dengan cara reduksi, display, dan verifikasi data dan dibandingkan dengan hasil observasi dan wawancara.

\section{Hasil Penelitian dan Pembahasan \\ Isu dan Pemetaan Konflik Komunikasi di Objek Wisata Pantai Buges}

Objek wisata Pantai Buron dan Gesing (Buges) mulai dikembangkan pada akhir tahun 2016. Pada awalnya Pantai Gesing merupakan salah satu pantai untuk singgah nelayan yang melaut. Sekelompok masyarakat sekitar yang melihat potensi Gesing sebagai objek wisata berinisiatif untuk mengembangkan infrastruktur sebagai pendukung. Seiring berjalannya waktu, dengan adanya pengembangan objek wisata oleh Pokdarwis dan masyarakat sekitar, jumlah wisatawan mulai meningkat. Peningkatan wisatawan yang datang sebagai salah satu pertimbangan Pemkab Gunungkidul untuk menerapkan perda penarikan retribusi terkait kegiatan pariwisata. Pada tanggal 1 Januari
2019, Dinas Pariwisata mulai menetapkan retribusi resmi untuk memasuki objek wisata di desa Girikarto. Penetapan retribusi ini menjadi inti permasalahan dalam konflik ini. Penarikan retribusidariDinasPariwisatabekerjasamadengan Pemerintah Desa sebagai petugas dan pengelola retribusi tersebut. Pihak pokdarwis dalam hal ini Pak Surgiyono selaku ketua pokdarwis merasa keberatan dengan tidak diikutsertakannya pokdarwis dalam mengelola retribusi tersebut.

Konflik yang terjadi pada pengelolaan pariwisata dengan objek wisata Pantai Buges dipetakan ke dalam permasalahan konflik yang berbeda. Pemetaan konflik di objek wisata Pantai Buges desa Girikarto, Panggang berdasarkan pemetaan diatas dapat dilihat secara garis besar dalam dua permasalahan, yaitu; (1) Konflik antara Pokdarwis dengan Pemerintah Kabupaten Gunungkidul. (2) Konflik antara kelompok sadar wisata (Pokdarwis) dengan anggotanya.

\section{Isu dan Pemetaan Konflik Komunikasi di Objek Wisata Watugupit}

Objek wisata Watugupit sejak awal dikelola langsung oleh Dinas Pariwisata Gunungkidul. Pengembangan objek wisata ini mulai berkembang dan dikenalkan secara luas ke masyarakat umum pada akhir 2017. Melihat antusiasme wisatawan yang mulai meningkat dan disertai pembangunan fasilitas, Pemkab mulai memberlakukan penarikan retribusi untuk masuk ke wilayah objek wisata Paralayang Watugupit ini. Penarikan retribusi di objek wisata Watugupit tertuang dalam Peraturan Daerah (perda) Kabupaten Gunungkidul Nomor 5 Tahun 2017 Tentang Perubahan Kedua Atas Peraturan Daerah Kabupaten Gunungkidul Nomor 6 Tahun 2012 Tentang Retribusi Tempat Rekreasi dan Olah Raga. Dalam mengembangkan objek wisata Watugupit, pemerintah kabupaten mengikutsertakan masyarakat sekitar untuk berpartisipasi dalam pengelolaannya. Pos penarikan retribusi menuju objek wisata 
Paralayang Watugupit terdapat di dua tempat dan dua desa yang berbeda, yaitu desa Giricahyo dan desa Girijati. Banyaknya wisatawan yang berkunjung dari arah Bantul, dimana melewati pos penjagaan retribusi di desa Girijati membuat permasalahan tersendiri. Adanya kecemburuan masyarakat desa Giricahyo yang melihat banyaknya wisatawan yang melalui pos retribusi tersebut. Pada awalnya konflik tersebut melibatkan masyarakat antar dua desa yaitu Giricahyo dan Girijati sebagai pengelola objek wisata Paralayang Watugupit terkait retribusi. Dalam perkembangannya permasalahan tersebut ikut menyeret Pemerintah Daerah Kabupaten Gunungkidul sebagai pemilik lahan sekaligus pengelola objek wisata tersebut.

\section{Dinamika Konflik Komunikasi di Objek Wisata Pantai Buges}

Sejak penetapan Pokdarwis Alam Asri sebagai kelompok sadar wisata di kawasan Pantai Gesing, pokdarwis mulai membangun sarana dan prasarana. Setelah membangun fasilitas penunjang, pokdarwis mulai melakukan penarikan retribusi untuk memasuki kawasan wisata Pantai Buron dan Gesing. Sebelum perda terkait retribusi ditetapkan, Pemkab melakukan koordinasi dengan pihak pokdarwis dan pemdes Girikarto untuk memperkirakan kondisi di pantai Buges. Dalam koordinasi yang yang sudah dilakukan, pihak pokdarwis pada awalnya menerima kebijakan yang akan diberlakukan oleh pemkab Gunungkidul apabila anggota pokdarwis diikutsertakan dan dilibarkan dalam pelaksanaannya, akan tetapi pihak pemerintah desa dan pokdarwismemilikiperbedaan pendapat.

Penerapan retribusi sesuai perda no 2 tahun 2018 tentang perubahan ketiga atas peraturan daerah kabupaten Gunungkidul nomor 6 Tahun 2012 tentang retribusi tempat rekreasi dan olah raga dilakukan serentak pada tanggal 1 Januari 2019 di objek wisata pantai Buges dan menjadi gejolak bagi pengelola maupun wisatawan yang datang. Proses sosialisasi Perda menimbulkan perbedaan dalam pemaknaan pesan yang menimbulkan pertentangan dari pihak pokdarwis. Pokdarwis tetap melakukan pungutan terhadap wisatawan yang datang dan tidak memperdulikan perda. Hal ini mengakibatkan wisatawan yang datang harus membayar retribusi dua kali untuk masuk ke wilayah pantai Buges. Adanya pertentangan yang terjadi akibat proses komunikasi yang berjalan tidak baik antara pokdarwis dengan Pemkab mengakibatkan konflik dalam mengelola wisata Pantai Buges.

Proses komunikasi antara pokdarwis dengan Pemerintah Desa Girikarto yang sudah terputus menimbulkan kecurigaan dan pertentangan. Ketidakterbukaan informasi dari kedua belah pihak merupakan hambatan dari kegiatan komunikasi dalam mengelola potensi wisata pantai Buges. Informasi yang diperoleh oleh Pemerintah Desa Girikarto tidak disampaikan secara langsung ke pokdarwis begitu pula sebaliknya. Hal ini mengakibatkan ketika adanya kesepakatan yang dijalin oleh perangkat desa Girikarto mengenai pengelolaan pantai Buges tidak disampaikan langsung kepada pokdarwis.

Konflik di pantai Buges mulai memuncak menjelang libur lebaran 2019. Setelah adanya pemasangan portal yang dilakukan oleh petugas desa dan anggota Polsek setempat, konflik masih terjadi di Pantai Gesing. Beberapa anggota pokdarwis melakukan perusakan gapura masuk menuju Pantai Gesing. Dalam konflik yang terjadi saat itu, beberapa anggota diamankan oleh polisi setempat. Walaupun sudah diminimalisir, tetapi konflik yang terjadi pada hari kedua lebaran tersebut berdampak langsung kepada wisatawan yang datang.

Setelah konflik yang memanas pada bulan Juni 2019, pihak pemerintah desa yang telah ditunjuk langsung oleh Dinas Pariwisata berusaha melakukan negosiasi dengan Sargiyono selaku ketua Pokdarwis. Dalam negosiasi tersebut, pihak pemerintah desa menawarkan kesepakatan mengenai pembagian hasil dalam pengelolaan objek wisata di Pantai Gesing. 
Bapak Sargiyono merasa pembagian tersebut tidak adil dikarenakan tidak adanya partisipasi pemerintah desa dalam pengembangan pariwisata di Pantai Gesing secara langsung. Tindak lanjut yang dilakukan oleh Pemerintah daerah dengan adanya konflik yang terjadi dan berdampak langsung kepada wisatawan adalah dilakukannya kembali mediasi antar pihak-pihak yang terkait. Guna menyelesaikan konflik komunikasi yang terjadi di pantai Buges, pemerintah Desa Girikarto menyerahkan penyelesaian kepada Pemkab Gunungkidul. Permasalahan konflik sosial di pantai Buges hingga saat ini belum menemukan titik temu. Komunikasi yang dijalin oleh seluruh stakeholders dalam pengelolaan wisata pantai Buges hingga saat ini belum menemukan strategi yang tepat untuk menyelesaikan konflik yang terjadi. Dalam setiap kesempatan yang ada untuk berdialog, masing-masing pihak lebih mementingkan kepentingan masing-masing. Opsi yang diberikan oleh Pemkab Gunungkidul tidak menyelesaikan permasalahan yang ada.

Dinamika konflik komunikasi juga terlihat dalam internal organisasi pokdarwis Alam Asri. Pokdarwis ini pada awalnya dibentuk karena adanya kepedulian masyarakat sekitar untuk mengembangkan potensi wisata di pantai Buron dan Gesing dengan diketuai oleh Aris Sargiyono. Anggota dari pokdarwis ini juga merupakan masyarakat sekitar pantai dan pelaku usaha yang sudah berdiri di pantai Gesing cukup lama.

Pokdarwis Alam Asri memiliki struktur organisasi yang lengkap dan memiliki Anggaran Dasar (AD) atau Anggaran Rumah Tangga (ART) yang mengatur kegiatan mereka. Kepengurusan pokdarwis secara resmi hanya bertahan beberapa bulan setelah diresmikan oleh Dinas Pariwisata. Banyak pengurus yang mengundurkan diri dikarenakan visi misi yang ditetapkan saat awal pembentukan tidak sesuai dengan pelaksanaannya. Pengurus pokdarwis Alam Asri banyak yang mengundurkan diri atau memilih tidak aktif sebagai pengurus. Mereka merasa bahwa Pak Sargiyono sebagai ketua hanya mementingkan kepentingan pribadinya. AD/ART yang sudah disusun dari kesepakatan bersama tidak dilaksanakan oleh ketua.

\section{Dinamika Konflik Komunikasi di Objek Wisata Watugupit}

Penetapan retribusi di Watugupit dilakukan pada awal tahun 2018. Pembangunan dan perbaikan sarana-prasarana di objek Wisata Paralayang Watugupit dilakukan oleh Dinas Pariwisata untuk membuat nyaman wisatawan. Masyarakat sekitar turut serta berpartisipasi dalam pengembangan objek wisata Paralayang Watugupit. Akan tetapi, geografis objek wisata ini berada di dua desa yang berbeda.

Banyaknya wisatawan yang berkunjung dari arah Bantul, dimana melewati pos penjagaan retribusi di desa Girijati membuat permasalahan tersendiri. Adanya kecemburuan masyarakat Desa Giricahyo yang melihat banyaknya wisatawan yang melalui pos retribusi tersebut. Ketimpangan perolehan hasil yang diperoleh masyarakat dari dua desa tersebut menjadi pemicu konflik yang terjadi. Perselisihan terjadi antar masyarakat dan melibatkan perangkat desa masing-masing. Negosiasi awal antara masyarakat Giricahyo dan Girijati dihasilkan perjanjian adanya kerjasama antara masyarakat di dua desa tersebut. Perwakilan masyarakat yang bertugas sebagai petugas retribusi dari desa Giricahyo ikut melakukan penarikan di pos retribusi Girijati. Hal ini juga berlaku pada masyarakat Girijati yang mengirimkan perwakilannya untuk berjaga di pos Giricahyo. Hasil negosiasi ini hanya berjalan selama satu minggu. Batalnya perjanjian yang telah disepakati oleh masyarakat Giricahyo dan Girijati, menjadikan konflik kembali terjadi.

Konflik yang terjadi ini tidak menemui titik temu dikarenakan adanya perdebatan yang terjadi baik di masyarakatnya maupun di pemerintah desa masing-masing. Hal ini juga diperparah dengan adanya laporan intimidasi 
dari masyarakat Girijati terhadap masyarakat Giricahyo yang bertugas di pos retribusi mereka. Dalam perkembangannya, penanganan konflik di mediatori oleh pihak kecamatan dan Dinas Pariwisata. Pertemuan-pertemuan dilakukan secara formal dan informal. Dinas Pariwisata selaku pengelola objek wisata Paralayang Watugupit mencoba memediasi masyarakat Giricahyo dan Girijati terkait retribusi masuk. Dalam dialog dan negosiasi yang dilakukan oleh Pemkab Gunungkidul dihasilkan kesepakatan bersama untuk mengelola retribusi masuk objek wisata Paralayang Watugupit. Kesepakatan yang diambil yaitu adanya pembagian tugas antara masyarakat dua desa di pos yang terdapat di masing-masing wilayahnya.

\section{Aktor Konflik Komunikasi di di Objek Wisata Pantai Buges dan Watugupit}

Adapun aktor-aktor yang terlibat dalam konflik ini dapat dikelompokkan sebagai berikut, (1) Kelompok Sadar Wisata (Pokdarwis), (2) Masyarakat Desa Girikarto, (3) Pemerintah Kabupaten Gunungkidul yang dibagi menjadi beberapa pihak, yaitu Pemerintah Desa Girikarto, Dinas Pariwisata Gunungkidul, dan Pemerintah Kabupaten Gunungkidul.

Konflik yang terjadi di objek wisata Paralayang Watugupi melibatkan beberapa orang atau aktor-aktor didalamnya yang dikelompokkan sebagai berikut; (1) Masyarakat Giricahyo, (2) Masyarakat Girijati, Pemerintah Kabupaten Gunungkidul dalam hal ini dibagi menjadi Pemerintah Desa Giricahyo, Pemerintah Desa Girijati, Pemerintah Kecamatan Purwosari, dan Dinas Pariwisata Gunungkidul.

\section{Penyebab Konflik Komunikasi di Objek Wisata Pantai Buges, yaitu: Faktor Perbedaan Kepentingan:}

Perbedaan kepentingan pada masalah, pemaknaan komunikasi dalam hubungan sosial menimbulkan konflik komunikasi. Dalam konflik yang terjadi pada pengelolaan objek wisata pantai Buges, perbedaan kepentingan terjadi antara masyarakat desa Girikarto yang tergabung dalam pokdarwis dengan pemerintah kabupaten mengenai pengelolaan obwis pantai Buges. Pihak-pihak yang berkonflik menyampaikan naratif pesan yang berkaitan dengan kepentingan mereka masing-masing terkait kebijakan yang ada.

Masing-masing pihak memiliki gaya komunikasi sendiri. Gaya komunikasi yang dilakukan oleh bapak Sargiyo yang mengatasnamakan pokdarwis terlihat dominan dalam menyampaikan pesan baik dalam berdialog dengan Pemerintah kabupaten maupun menyampaikan narasi kepentingannya dengan masyarakat. Sebagai komunikator pak Sargiyono melakukan komunikasi secara agresif. Gaya komunkasi yang dilakukan oleh Dinas Pariwisata berbeda dengan Pak Sargiyo. Dinas pariwisata (dispar) sebagai komunikator yang bersikap ramah tamah dan sopan saat sedang menyampaikan pesan kepada penerima pesan. Sebagai bagian dari lembaga pemerintahan, dispar menggunakan gaya komunikasi yang berstruktur dengan memanfaatkan pesan verbal secara tertulis maupun lisan untuk memantapkan perintah yang harus dilaksanakan, akan tetapi dalam pelemparan pesan kurang dapat membaca perubahan-perubahan yang tejadi di masyarakat. Pemdes Girikarto sebagai bagian dari lembaga pemerintah yang memiliki kepentingan di Pantai Buges mempunyai gaya komunikasi yang pasif dalam menanggulangi konflik yang ada. Sebagai komunikator mereka lebih sering menghindari secara langsung dengan pihak yang bersebrangan.

Persepsi dalam penyampaian pesan yang dilakukan selama proses komunikasi merupakan bagian dari konflik yang terjadi. Perbedaan persepsi dalam pemaknaan pesan yang disampaikan oleh stakeholders dalam konflik ini disebabkan faktor oleh politik dan ekonomi. Berkembangnya pariwisata di Pantai Buges menjadi salah satu tempat untuk mencari nafkah bagi para penduduk Desa Girikarto. Dalam perkembangannya menimbulkan konflik di dalam masyarakat untuk memperbutkan serta mempertahankan potensi ekonomi di pantai Buges. 


\section{Faktor Perbedaan Nilai}

Konflik internal yang terjadi di internal organisasi pokdarwis Alam Asri dikarenakan adanya perbedaan dalam nilai-nilai atau persepsi antara kesatuan organisasi tersebut. Perbedaan tujuan yang diharapkan oleh beberapa pengurus dengan ketua terlihat dalam pelaksanaan aktivitas pokdarwis Alam Asri. Pengurus merasa mempunyai hak untuk ikut andil dalam menentukan program dan aktivitas yang dilakukan oleh pokdarwis. Dalam pengelolaan pokdarwis komunikasi antara ketua dan pengurus tidak berjalan semestinya. Program-program yang dilaksanakan dilakukan sesuai dengan kebijakan yang diambil oleh ketua, sedangkan pengurus tidak dilibatkan dalam pengambilan keputusan mengenai kebijakan tersebut.

Perbedaan nilai memicu terjadinya konflik dalam komunikasi manakala masing-masing yang terlibat dalam komunikasi gagal untuk menerima adanya perbedaan nilai tersebut. Hal ini terlihat dengan adanya ide dan pendapat yang berseberangan dalam kepengurusan dan mengakibatkan banyaknya pengurus yang memilih untuk mengundurkan diri.

\section{Penyebab Konflik Komunikasi di Objek Wisata Watugupit, yaitu: Konflik Kepentingan.}

Dalam konflik yang terjadi pada pengelolaan objek wisata Paralayang Watugupit, perbedaan kepentingan terjadi antara masyarakat Desa Giricahyo dan Desa Girijati yang tergabung dalam kelompok- kelompok yang masingmasing mengklaim berhak ikut serta mengelola objek wisata tersebut. Proses komunikasi dalam menyampaikan pesan mengenai kepentingan masing-masing pihak dikarenakan adanya faktor-faktor yang menghambat dalam kegiatan komunikasi untuk mengelola objek wisata Watugupit.

Adanya kesalahpahaman dalam perbedaan hasil yang didapat oleh masyarakat Desa Gicahyo menjadi pemicu konflik yang terjadi. Kegagalan komunikasi dapat membuat seseorang membuat asumsi yang salah dan lebih percaya pada kabar burung. Perangkat Desa Giricahyo dan Girijati yang sering tidak mau bertemu secara langsung menjadi salah satu penyebab konflik yang terjadi tidak diatasi secepatnya. Salah satu pihak memilih menghindar untuk menyelesaikan konflik menyebabkan tidak tersampaikannya pesan dari pihak lain. Pertukaran pesan tidak terjadi dikarenakan interaksi tidak terjalin dua arah.

\section{Bentuk Konflik Komunikasi di Objek Wisata Pantai Buges dan Watugupit}

Konflik vertikal yang terjadi dalam pengembangan objek wisata pantai Buges yaitu antara pihak pokdarwis berhadapan dengan Pemerintah Kabupaten (Pemkab) Gunungkidul dalam hal ini Pemerintah Desa Girikarto dan Dinas Pariwisata Gunungkidul. Akar permasalahan yang menyebabkan konflik vertikal ini terjadi yaitu adanya ketidakpuasan yang dirasakan oleh pihak Pokdarwis terhadap Pemkab Gunungkidul, baik mengenai sikap maupun kebijakan yang diambil oleh pihak Pemkab dalam menanganai konflik pengelolaan pantai Buges mengenai retribusi masuk ke objek wisata. Konflik horizontal didalam permasalahan ini terjadi antara masyarakat dengan kelompok sadar wisata (Pokdarwis) dan antara pengurus dan anggota pokdarwis Alam Asri di objek wisata pantai Buges.

Konflik yang terjadi dalam pengelolaan objek wisata Paralayang Watugupit ini timbul pertentangan secara horizontal. Pertentangan dikarenakan kedudukan kedua kelompok yang berseberangan masih dalam derajat ataupun setatus yang setara antara satu dengan lainnya. Konflik horizontal ini diawali dengan adanya klaim masyarakat Desa Giricahyo mengenai geografis tempat objek wisata Paralayang Watugupit berada di desa tersebut sehingga masyarakat mengklaim berhak atas pengelolaan retribusi masuk objek wisata namun mendapat penolakan dari pihak masyarakat desa Girijati. Masyarakat Girijati juga mengklaim jalan menuju ke objek wisata tersebut melewati wilayah itu. 


\section{Strategi Pengelolaan Konflik Komunikasi di} Objek Wisata Pantai Buges

Kompetisi. Konflik komunikasi yang terjadi di pantai Buges gaya kompetisi memperlihatkan persaingan yang dilakukan oleh pihak-pihak terkait untuk mencapai tujuan mereka. Strategi Kompetisi dalam pengelolaan konflik komunikasi terlihat dalam tindakan seperti berikut; Pak Sargiyono mengatasnamakan pokdarwis tetap menarik pungutuan masuk objek wisata; Pemdes mengajukan draft pembagian hasil ke Pemkab dalam pengelolaan retribusi Buges; Komunikasi yang terjalin antar pihak tidak berkoordinasi terlebih dahulu; Mengikutsertakan pengacara dan LBH untuk mewakili masing-masing pihak yang berkonflik sebagai komunikator dalam berdialog; Mantan pengurus pokdarwis tetap menjalankan usahanya di pantai Buges tetapi menolak aturan dan tidak berinteraksi dengan pokdarwis.

Penghindaran. Penghindaran dilakukan oleh pihak-pihak yang berkonflik untuk tidak menambah masalah ataupun dikarenakan merasa tidak sesuai dengan kepentingan mereka, seperti halnya: Pokdarwis tidak menghadiri rapat koordinasi yang diadakan Pemdes; Pokdarwis tidak mengikuti acara yang diadakan di pantai BugesDalam kunjungan Pemdes tidak berinteraksi langsung dengan pak Sargiyono; dan Mantan pengurus pokdarwis tidak mau disangkutkan dengan konflik yang terjadi antara pak Sargiyono dengan Pemkab.

Kompromi. Tindakan yang dilakukan adalah melakukan negosiasi, mencari persetujuan dan menjual ide, dan menemukan solusi yang menarik dan dapat diterima. Tindakan kompromi yang dilakukan oleh Pemkab antara lain; Pemkab dan Dispar Gunungkidul menjadi mediator dalam permasalan yang terjadi; Dispar memberikan ide bagi kedua belah pihak; Pemdes membuat draft untuk mengikutsertakan pokdarwis sebagai petugas pungut di pos tpr Buges. Tindakan kompromi ini masih tidak ada titik temu penyelesaian konflik yang terjadi.
Akomodasi. Dinas Pariwisata yang mempunyai kekuasaan dalam pengelolaan objek wisata menekankan kekuataan yang dimilikinya dalam menyelesaikan konflik. Pemerintah desa Girikarto menyerahkan keputusan kepada Dinas Pariwisata terkait kebijakan retribusi masuk objek wisata pantai Buges.

\section{Strategi Pengelolaan Konflik Komunikasi di Objek Wisata Watugupit}

Persaingan. Persaingan yang terjadi terlihat dari interaksi yang dilakukan oleh masyarakat di kedua pihak. Masing-masing pihak merasa memiliki persamaan hak dalam pengelolaan retribusi masuk objek wisata yang merupakan prinsip dominan dalam hubungan sosial. Salah satunya, adanya intimidasi dari salah satu pihak untuk mempertahankan kepentingan mereka.

Penghindaran. Masing-masing kelompok yang berseteru berusaha menghindari satu sama lain untuk tidak berkomunikasi sehingga tidak memperkeruh permasalahan. Hal ini terlihat dengan adanya upaya pengalihan topik saat membicarakan konflik yang sedang terjadi dan ketika diadakanmediasi oleh pihak kecamatan dan dinas kades Girijati tidak berkenan untuk datang.

Kompromi. Dengan mengedepankan kepentingan bersama, proses negosiasi antar masyarakat Giricahyo dan Girijati dapat dilakukan dan mencapai kesepakatan. Kompromi yang dilakukan seperti menjalin kesepakatan bersama antara masyarakat Giricahyo dan Girijati yang bertahan selama satu minggu. Pemerintah kecamatan Purwosari dan Dispar Gunungkidul sebagai mediator antara dua desa yang berselisih.

Akomodasi. Pemda Gunungkidul dalam hal ini Dinas Pariwisata dan pemerintah kecamatan memiliki kekuasaan untuk mengatur kebijakan yang diambil guna mengedepankan kepentingan bersama. Pemkab memberikan opsi kerjasama untuk masyarakat dua desa tersebut.

Kolaborasi. Kolaborasi yang dilakukan dalam pengelolaan objek wisata Paralayang Watugupit dilakukan oleh semua pihak yang 
berkonflik yaitu dengan cara masing-masing individu maupun kelompok dalam masyarakat saling menjaga dan menarik diri dari pertikaian danlebih mengutamakan kepentingan masyarakat secara umum dibandingkan kepentingankepentingan kelompok semata. Kolaborasi terlihat dimana Dispar Gunungkidul sebagai pengelola objek wisata Paralayang Watugupit dan adanya pembagian tugas antara masyarakat desa Giricahyo dan Girijati di masing-masing TPR masuk objek wisata Paralayang Watugupit.

\section{Dampak Konflik Komunikasi di Objek Wisata Pantai Buges}

Dampak positif yang ditimbulkan adalah memungkinkan adanya penyesuaian kembali norma-norma, nilai-nilai, serta hubunganhubungan sosial. Hubungan sosial dalam pengelolaan pantai Buges dapat disesuaikan kembali dengan norma-norma dan nilai-nilai sesuai dengan kearifan lokal dalam masyarakat. Sebagai sarana untuk mencapai keseimbangan antara kekuatan-kekuatan dalam masyarakat, dimana kekuatan dari masing-masing kelompok dapat disesuaikan dengan fungsinya masingmasing untuk mengembangkan potensi-potensi wisata di pantai Buges. Memunculkan sebuah kompromi baru, sebuah kompromi baru akan muncul dengan mengikutsertakan seluruh aspek baik dari lembaga terkait, pokdarwis yang berada di lapangan dan masyarakat berpartisipasi dalam pengelolaan objek wisata pantai Buges.

Dampak negatif dalam konflik komunikasi dapat mengakibatkan antara lain, perpecahan di masyarakat dalam banyak hal dan peristiwa. Konflik komunikasi yang terjadi dalam pengelolaan objek wisata pantai Buges berdampak pada berkurangnya tingkat kerukunan dalam masyarakat bahkan terjadi sikap saling curiga. Apabila konflik tidak kunjung usai akan berdampak pada timbulnya benih-benih permusuhan dalam masyarakat yang justru dapat mengakibatkan konflik semakin meluas. Konflik komunikasi yang terjadi menimbulkan adanya perasangka negatif dalam benak pihak-pihak yang terlibat seperti Pemkab Gunungkidul, pengelola pokdarwis maupun masyarakat Desa Girikarto itu sendiri. Komunikasi verbal yang mengarah pada kekerasan juga banyak dilakukan. Tindakan tersebut banyak terjadi dalam mediasi yang dilakukan secara formal maupun informal baik melalui tatap muka langsung ataupun komunikasi melalui chat massanger.

\section{Dampak Konflik Komunikasi di Objek Wisata Watugupit}

Dampak positif yang ditimbulkan adalah tuntasnya permasalahan, adanya berbagai kesepakatan yang telah terjalin diantara kelompok yang berkonflik dalam pengelolaan objek wisata Paralayang Watugupit, terdapat berbagai kesepakatan yang menunjukkan bahwa konflik yang terjadi dapat diselesaikan. Menciptakan Integrasi yang Harmonis, kesepakatan untuk mengakhiri konflik menciptakan integrasi yang harmonis yang dapat dibangun oleh setiap kelompok yang bertikai. Memunculkan kompromi baru, dengan adanya konflik yang terjadi dan perjanjian sehingga pengelolaannya dilakukan secara bersama.

Dampak negatif dalam konflik komunikasi yang terjadi yaitu terjadinya perpecahan diantara kelompok masyarakat di dua desa tersebut saling curiga. Konflik komunikasi dalam pengelolaan Paralayang Watugupit mengenai pembagian tugas retribusi masuk apabila tidak kunjung usai akan berdampak pada timbulnya benih-benih permusuhan dalam masyarakat dua desa tersebut yang dapat mengakibatkan konflik semakin meluas. Adanya perasangka negatif yang timbul dalam benak masyarakat desa Giricahyo dan Girikarto dikarenakan konflik komunikasi.

Dalam konflik komunikasi, pesan memegang peranan penting dalam meningkatkan pertentangan dan mungkin juga perselisihan yang muncul di dalamnya. Konflik masyarakat yang terjadi dalam pengelolaan pariwisata di Gunungkidul memperlihatkan suatu proses 
interaksi dan komunikasi yang komunikatif dalam sistem sosial budaya. Konflik pengelolaan pariwisata yang terjadi di Gunungkidul di sebabkan karena kurangnya perhatian Pemerintah Daerah terhadap peran masyarakat sekitar atau pokdarwis yang telah terlebih dahulu mengembangkan potensi wisata di daerah tersebut. Kurangnya komunikasi oleh Pemerintah Daerah dengan masyarakat ditunjukkan dari kurangnya tingkat partisipasi masyarakat sebelum menjalankan kebijakan penyelengaraan pemerintah dan pembangunan di wilayah objek wisata dalam hal ini pantai Buges.

LangkahpersuasiPemdauntukmeningkatkan partisipasi masyarakat lokal masih banyak hambatan. Keberhasilan persuasi Pemda terhadap masyarakat lokal di objek wisata Pantai Buges dan Watugupit berbeda. Pemda Gunungkidul dikatakan berhasil mengajak masyarakat Girijati dan Giricahyo untuk bersama-sama mengelola objek wisata Watugupit, tetapi hal ini tidak berlaku di objek wisata Pantai Buges.

Hasil penelitian ini menunjukkan konflik dalam pengelolaan objek wisata pantai Buges sangat beragam. Konflik yang terjadi dikarenakan polemik adanya double retribusi di objek wisata pantai Buges setelah adanya penetapan Perda nomor 2 tahun 2018 mengenai pungutan retribusi. Sedangkan konflik yang terjadi di objek wisata Paralayang Watugupit dikarenakan adanya kecemburuan yang terjadi antara dua desa dalam pemungutan retribusi masuk objek wisata Paralayang. Adanya permasalahan dalam komunikasi menjadi hal utama dalam proses manajemenkonflikdipantaiBuges dan Watugupit.

Pemda Gunungkidul dan pokdarwis Alam Asri sebagai pengelola pantai Buges tidak dapat mengelola potensi wisata yang ada secara baik. Partisipasi dalam pengelolaan potensi wisata tidak hanya dilakukan satu pihak, tetapi seluruh pihak yang terkait. Keterlambatan Pemda untuk berpartisipasi dari awal dalam mengembangkan potensi wisata yang ada menjadi salah satu permasalahan yang ada. Persuasi yang dilakukan oleh Pemda terhadap pokdarwis tersebut tidak berjalan sebagaimana semestinya. Interaksi yang terjalin dalam pengelolaan pariwisata di Buges tidak memperlihatkan adanya komunikasi dua arah yang baik. Proses komunikasi yang dilakukan dalam konflik pengelolaan objek wisata Pantai Buges dan Watugupit menimbulkan pola aksi-reaksi yang berbeda. Konflik yang terjadi dalam pengelolaan pariwisata di Gunungkidul banyak terjadi dikarenakan distribusi manfaat yang tidak merata atau suara yang tidak sama dalam tujuan pembangunan.

Strategi kolaborasi tidak dapat dijalankan oleh Pemda Gunungkidul dalam menyelesaikan permasalahan di salah satu konflik yang berlangsung. Gagalnya proses komunikasi untuk berdialog menyamakan tujuan dalam mengembangkan potensi wisata di Pantai Buges memperlihatkan manajemen konflik yang dilakukan oleh Pemda kurang tepat. Putnam (2006; 2) menjelaskan bahwa konflik membentuk aspek-aspek tertentu dalam masyarakat terutama yang berhubungan dengan interaksi sosial seperti bentuk-bentuk pertentangan dan perjuangan, sehingga secara keseluruhan konflik dan komunikasi berkait dengan hubungan resiprokal.

Narasi yang diberikan oleh masing-masing aktor berbeda baik dalam konflik yang terjadi di Pantai Buges maupun di Watugupit. Narasi yang disampaikan oleh pak Sargiyono sebagai ketua pokdarwis dalam konflik dengan Pemda yaitu sebagai pihak yang terdzolimi dengan adanya kebijakan Perda tersebut. Hal ini bertolak belakang dengan narasi yang disampaikan oleh Dispar dan Pemdes Girikarto sebagai lembaga pemerintahan Gunungkidul. Mereka melakukan negosiasi untuk menyertakan pihak pokdarwis dalam menjalankan kebijakan tersebut. Narasi yang disampaikan oleh masing-masing pihak menimbulkan persepsi yang berbeda mengenai konflik yang terjadi. 
Dalam konflik pengelolaan Watugupit, masyarakat Giricahyo dan Girijati melihat nilainilai sosial untuk mencapai tujuan mereka. Pemda Gunungkidul dalam hal ini Dinas Pariwisata dan pemerintah kecamatan memiliki kekuasaan untuk mengatur kebijakan yang diambil guna mengedepankan kepentingan bersama. Dalam interaksi sosial, power memiliki tupoksi yang sangat menentukan (Tjabolo, 2017).

Dialog yang dilakukan dalam konflik Watugupit dapat menyelesaikan masalah yang terjadi antara masyarakat dua desa. Adanya social trust dari masyarakat dan penyampaian kontrak sosial yang dijalin oleh Pemda Gunungkidul dikarenakan komunikasi dalam menyamakan persepsi tujuan bersama dilakukan dengan baik. Dispar dan Pemerintah Kecamatan Purwosari dapat mengubah persepsi kecemburuan sosial dari masingmasing desa menjadi kesempatan bekerjasama untuk mendapatkan hasil yang lebih baik.

Dalam proses manajemen konflik diperlukan adanya strategi yang membangunan konsensus, sebuah alternatif untuk ketidaksetaraan yang melekat dalam bentuk konfrontasi atau permusuhan dari negosiasi pemangku kepentingan. Dalam kasus konflik pengelolaan wisata pantai Buges, peneliti melihat pendekatan manajemen konflik berdasarkan pembangunan konsensus multi-stakeholders memiliki banyak manfaat jika diterapkan dalam penanganan konflik yang terjadi.

Coser menyatakan konflik adalah sebagai suatu yang inheren dalam sistem masyarakat yang tidak lepas dari fakta hubungan kekuasaan dalam sistem sosial dan sifat kekuasaan yang mendominasi dan diperebutkan. Hubungan kekuasaan dalam sistem sosial menciptakan steering problem. Hal ini terlihat dalam konflik di pantai Buges dimana Dinas Pariwisata Gunungkidul menyampaikan kepada kepala desa Girikarto apabila tidak dapat mengatasi permasalahan dengan pokdarwis, dinas akan mengambil alih pengelolaan pantai
Buges secara penuh. Dinas Pariwisata yang mempunyai kekuasaan dalam pengelolaan objek wisata menekankan kekuataan yang dimilikinya dalam menyelesaikan konflik.

Hambatan terlihat dari tidak dapat dilakukannya kolaborasi dalam pengelolaan pariwisata di pantai Buges. Hambatan atau noise dalam permasalahan pantai Buges terjadi sejak awal pembentukan pokdarwis dan adanya perubahan perangkat desa. Informasi yang disampaikan kepada Pemdes tidak dilakukan secara transparan oleh ketua pengelola pokdarwis begitu pula sebaliknya sehingga menimbulkan persepsiyangberbeda. Dalamprosespenyelesaian konflik, Pemdes merasa tertekan dan tidak memiliki pilihan lain. Seperti yang diungkapkan oleh Coser, konflik merupakan kondisi dominasi struktural, kelompok yang berada di dalam struktur dengan berbagai perangkat kewenangan mampu mengarahkan berbagai bentuk kebijkan dan aturan main di luar struktur wewenang tersebut. Dinas Pariwisata mempunyai kewenangan dalam melakukan kebijakan yang sesuai untuk menyelesaikan konflik yang terjadi.

Munculnya konflik pada dasarnya disebabkan oleh adaya hubungan yang tidak terjalin dengan baik dan harmonis. Hal ini menyebabkan pesan dari salah satu pihak dapat dimaknai dalam maksud yang berbeda oleh pihak yang lain, sehingga menciptakan missing link dalam hubungan tersebut. Solusi untuk mencegah terciptanya potensi konflik di semua tingkat ialah dengan cara menghadirkan suasana komunikasi yang representatif, nyaman, dan harmonis baik secara individual, kelompok, maupun dengan komunitas dalam pengelolaan potensi wisata di Gunungkidul. Nilai-nilai kearifan lokal yang masih banyak melekat di masyarakat Gunungkidul merupakan salah satu strategi komunikasi yang dapat digunakan untuk melakukan pendekatan kepada masyarakat. Perasaan dihargai merupakan salah satu nilai dalam pertukaran sosial yang dijalin dengan adanya reward dan bagian dalam CBT. 


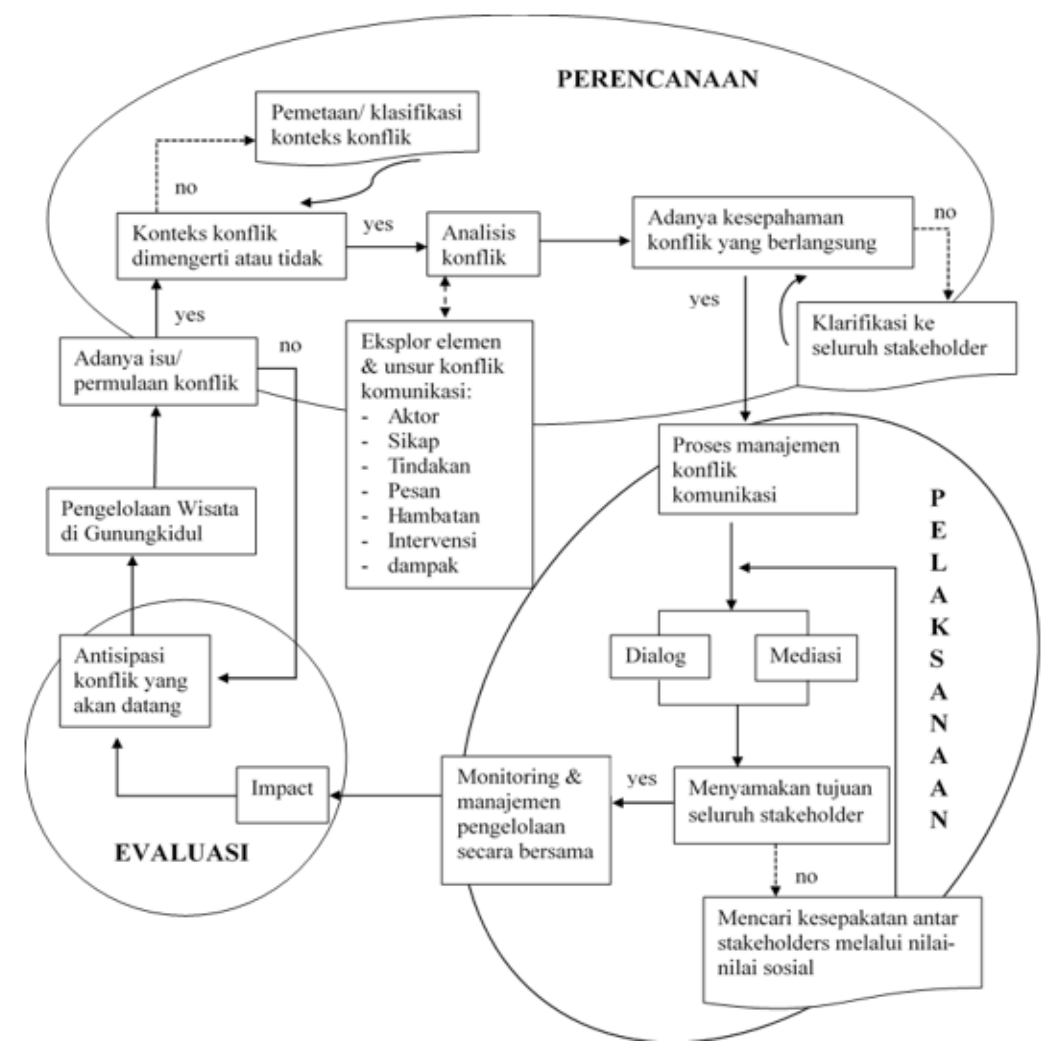

Gambar 1 Model Manajemen Konflik Komunikasi dalam pengelolaan pariwisata di Pantai Buges dan Watugupit Gunungkidul

Sumber: Dokumen Peneliti (2019)

Pemetaan Model Manajemen Konflik Komunikasi dalam Pengembangan CBT di Pantai Buges dan Watugupit Gunungkidul

Manajemen konflik meliputi kegiatan seperti: menstimulasi konflik, mengurangi atau menurunkan konflik, dan mengendalikan konflik. Konflik yang terjadi dalam pengelolaan pariwisata di pantai Gesing dan Watugupit pada dasarnya, disebabkan perbedaan kepentingan, perbedaan tujuan, perbedaan pendapat, dan perbedaan inisiatif dari masing-masing kelompok. Dalam penelitian ini, alternatif model pengelolaan konflik yang dapat diterapkan dalam kasus konflik di Gunungkidul terutama pantai Buges dan Watugupit menggunakan model manajemen konflik inovatif. Inovasi dalam pengelolaan konflik komunikasi diperlukan dengan upaya-upaya yang berdimensi kebaruan dan kebermanfaatan sehingga diharapkan dapat memberikan dampak pada upaya yang lebih kongkrit dan membangun partisipasi masyarakat secara berkesinambungan. Inovasi yang diciptakan dengan menggunakan kerangka kerja empat langkah yang terdiri dari reduce, eliminate, raise, create adalah dengan mengidentifikasi faktor-faktor apa saja yang harus dikurangi, dihapuskan, ditambah, dan diciptakan dalam manajemen konflik komunikasi untu mengembangan pariwisata di Gunungkidul terutama di Pantai Buges dan Watugupit. Penyelesaian konflik komunikasi dengan model inovatif dapat dilakukan dengan beberapa hal, yaitu:

Identifikasi peluang. Stakeholders dapat melihat peluang yang terdapat di objek wisata pantai Buges dan Watugupit dimana dapat dikelola secara bersama. Membangun rasa kepedulian dan saling memiliki potensi 
wisata dengan meningkatkan komitmen untuk mengembangkan pariwisata di obwis tersebut. Potensi wisata yang belum dimanfaatkan dapat digali dengan nilai-nilai sosial dan mengoptimalkan promosi secara bersama-sama.

Sikap proaktif. Diharapkan stakeholders bersikapproaktifterhadappermalahanyangterjadi jangan langsung menyimpulkan informasi yang diterima. Sikap proaktif juga dibarengi dengan keterlibatan seluruh aktor secara produktif untuk menyelesaikan konflik komunikasi yang terjadi.

Dinas Pariwisata sebagai lembaga resmi pengelola potensi wisata di Gunungkidul dapat mengadalan pelatihan SDM dalam mengelola kawasan pariwisata sesuai dengan sapta pesona. Pengetahuan yang tepat mengenai strategi pengelolaan potensi wisata dapat mendukung perkembangan pariwisata dan memperkecil potensikonflikyangterjadidiobjekwisatatersebut.

Mengembangkan sinergitas antara Pemerintah, swasta dan masyarakat. Diperlukan batas-batas kewenangan dan intervensi yang jelas antara pemerintah selaku regulator dan supervisor, swasta selaku fasilitator dan masyarakat/publik selaku operator. Adapun model manajemen konflik komunikasi dalam pengelolaan pariwisata di pantai Buges dan Watugupit yang diajukan oleh peneliti seperti Gambar 1 .

Perencanaan. Dalam tahap awal prosedur implementasi ini, perlu diadakan identifikasi masalah yang muncul dengan cara melihat gejala-gejala yang mengikutinya. Kedua, perlu dilakukan pengelompokan atau pengklasifikasian sumber konflik. Selanjutnya dilakukan analisis terhadap masalah atau sumber konflik yang muncul. Analisis dilakukan untuk mengetahui apakah termasuk kategori penting dan mendesak untuk diselesaikan atau dapat ditunda dengan memperhatikankemampuankelompok. Keempat, adanya kesepemahaman mengenai konflik yang berlangsung oleh seluruh stakeholders perlu dilakukan untuk mengelola bersama dalam mengembangkan potensi pariwisata.
Pelaksanaan. Pertama, eksplorasi mengenai keterlibatan dan pengembangan secara berurutan berpusat pada kepercayaan, sumber daya dan kekuasaan masing-masing, meskipun tingkat eksistensi masing-masing sumber konflik hadir di masing-masing tahap tujuan. Kedua, oposisi dalam tahap eksplorasi dapat ditandai dengan proses mediasi dan negosiasi antara para pihak berdasarkan kepercayaan dan sistem nilai masing-masing. Ketiga, Kerjasama atau aliansi antara individua tau kelompok penting untuk penyelesaian konflik. Tindakan inovatif perlu dilakukan untuk menyamakan tujuan stakeholders. Keempat, konflik bersifat dinamis dan membutuhkan pemantauan dan adaptasi jangka panjang yang sesuai. Interaksi yang terjalin dalam masyarakat memperlihatkan pola komunikasi sebagai bentuk atau pola hubungan stakeholders dalam proses pengiriman, dan penerimaan cara yang tepat sehingga pesan yang dimaksud dapat dipahami.

Evaluasi. Pengelolaan konflik yang telah dilakukan perlu diadakan evaluasi guna mengetahui lebih lanjut, bagaimana model ini dapat mengkonfirmasi bahwa kejadian konflik pada akhirnya menghasilkan dampak negatif atau positif. Model Manajemen Konflik Komunikasi dapat berfungsi sebagai alat pendukung keputusan dengan menciptakan platform untuk mengantisipasi dan belajar dari konflik. Model ini dapat diterapkan secara real-time dan dinilai kembali secara berkala untuk menentukan bagaimana keputusan manajemen mempengaruhi proses pengembangan pariwisata di daerah konflik.

\section{Simpulan}

Berdasarkan hasil penelitian model manajemen konflik komunikasi dalam pengelolaan pariwisata berbasis CBT di pantai Buges dan Watugupit dapat menggunakan model manajemen konflik komunikasi inovatif. Model manajamen konflik komunikasi terdiri dari tiga tahapan, yaitu perencanaan, pelaksanaan dan 
evaluasi. Inovasi dalam pengelolaan konflik komunikasi adalah dengan mengidentifikasi faktor-faktor apa saja yang harus dikurangi, dihapuskan, ditambah, dan diciptakan dalam manajemen konflik komunikasi untuk mengembangan pariwisata di Gunungkidul terutama di Pantai Buges dan Watugupit.

Peran Dinas Pariwisata sebagai penanggung jawab pengelolaan potensi wisata di Gunungkidul tidak maksimal dalam penanganan konflik komunikasi yang terjadi. Dinas Pariwisata Gunungkidul tidak memiliki panduan strategi manajemen konflik komunikasi yang tepat untuk menyelesaikan permasalahan yang ada terkait konflik komunikasi yang terjadi di pantai Buges dan tidak memiliki strategi untuk mengantisipasi konflik yang akan muncul dalam pengembangan kawasan wisata di Gunungkidul pada umumnya. Peran masyarakat lokal tidak banyak diikutsertakan dalam perancangan, pengambilan keputusan maupun pelaksanaan kebijakan dalam pengelolaan pariwisata di Gunungkidul sebagaimana yang terjadi di pantai Buges.

Tidak adanya komunikasi yang efektif dalam proses manajemen konflik dalam permasalahan di Gunungkidul dalam hubungan sosial baik dengan stakeholders dalam konflik yang berlangsung baik di objek wisata pantai Buges maupun di Watugupit, banyaknya hambatan dalam penyampaian pesan terlihat dalam proses manajemen konflik yang tidak ditangani dengan tepat untuk menemukan penyebab hambatan tersebut. Tidak adanya penyamaan tujuan yang dilakukan oleh stakeholders dalam mengelola pariwisata di Gunungkidul untuk mengantisipasi dan menyelesaikan konflik komunikasi yang terjadi. Penelitian ini memberikan kontribusi berupa model manajemen konflik yang dapat diterapkan pada dinas pariwisata lain dalam mengelola keindahan alam di suatu daerah.

\section{Daftar Pustaka}

Amin, M. A. S. (2017). Komunikasi Sebagai Penyebab Dan Solusi Konflik Sosial. Jurnal Common, 1(2). Curcija, Marcus., Breakey, Noreen., Driml, Sally. (2018). Development of a conflict management model as a tool for improved project outcomes in Community Based Tourism. Tourism Management: Elsevier, 70, 341-354. Jupir, M. M. (2013). Implementasi Kebijakan Pariwisata Berbasis Kearifan Lokal (Studi di Kabupaten Manggarai Barat). Journal of Indonesian Tourism and Development Studies, 1(1), 28-38. Lestari, P., DN, R., \& Hendariningrum, R. (2009). Manajemen Konflik berbasis Budaya Lokal sebagai upaya meningkatkan Jati diri Bangsa Indonesia. Jurnal Ikatan Sarjana Komunikasi Indonesia, 1(1), 73-96. Lestari, P., Prabowo, A., \& Wibawa, A. (2012). Manajemen komunikasi bencana merapi 2010 pada saat tanggap darurat. Jurnal Ilmu Komunikasi, 10(2). Littlejohn, Stephen W., Foss, Karen A. (2009). Encyclopedia of communication theory. United States of America: SAGE Publications, Inc. Nugraha, B. S., \& Putri, L. P. (2016). Analisis Dampak Lingkungan Dalam Kebijakan Perlindungan Situs Ratu Boko Menuju Pengembangan Pariwisata yang Berkelanjutan. Kepariwisataan: Jurnal Ilmiah, 10(2). Okazaki, E. (2008). A community-based tourism model: Its conception and use. Journal of Sustainable Tourism: Taylor \& Francis, 16(5), 511-529. Pamungkas, A. M. Y., Rahardjo, T., Dwiningtyas, H., \& Pradekso, T. (2015). Manajemen Konflik dan Negosiasi Wajah dalam Budaya Kolektivistik (Konflik Pembangunan Bandara di Kulon Progo). Interaksi Online, 4(1). 
Puspita, Weni. (2018). Manajemen Konflik (Suatu Pendekatan Psikologi, Komunikasi, dan Pendidikan). Yogykarta: Deepublish. Putnam Linda L. (2006). Definition and Approach to Conflict and Communication. The SAGE handbook of conflict communication: integrating theory, research, and practice. hal 1-32. Thousand Oaks, CA: Sage. Tjabolo, Siti Asiah. (2017). Manajemen Konflik Teori dan Aplikasi. Jakarta: Pustaka Cendekia.
Usman, Ridwan. (2001). Konflik dalam Perspektif Komunikasi: Suatu Tinjauan Teoretis. Mediator: Jurnal Komunikasi, 2(1). Yang, J., Ryan, C., \& Zhang, L. (2013). Social conflict in communities impacted by tourism. Tourism Management: Elsevier, 35, 82-93. Young, J. C., Thompson, D. B. A., Moore, P., MacGugan, A., Watt, A., \& Redpath, S. M. (2016). A conflict management tool for conservation agencies. Journal of Applied Ecology: Wiley Network, 53(3), 705-711. 